\title{
Assay of glucose transport in human fat cells obtained by needle biopsy
}

\author{
H. Yki-Järvinen ${ }^{1}$, E. A. Nikkilä ${ }^{1}$, K. Kubo ${ }^{2}$ and J.E. Foley ${ }^{2}$ \\ ${ }_{1}^{1}$ Third Department of Medicine, Helsinki University, Helsinki, Finland and \\ ${ }^{2}$ Clinical Diabetes and Nutrition Section, PECRB/NIADDK/NIH, Phoenix, Arizona, USA
}

\begin{abstract}
Summary. A method was developed for repeated measurements of glucose transport in human fat cells obtained by needle biopsy aspiration. Assay conditions, reproducibility and normal values of the measurements are described. Transport rates were measured in the absence and presence $(25,50,100$, $200,800 \mathrm{pmol} / \mathrm{l} ; 8,80 \mathrm{nmol} / 1)$ of insulin using $\mathrm{U}-\left({ }^{14} \mathrm{C}\right)$-D-glucose as the tracer. The extracellular glucose concentration was $1.5 \mu \mathrm{mol} / \mathrm{l}$. The reproducibility of glucose transport measurements was assessed by taking two needle biopsies from opposite sides of the same subject $(n=11)$. The mean coefficient of variation for maximal glucose transport was $11 \pm 6 \%$. In 14 subjects, a needle biopsy sample was aspirated immediately prior to surgical removal of fat. The maximal insulin-stimulated glucose transport rates averaged $143 \pm 15$ and $143 \pm$ $15 \mathrm{fl} / \mathrm{cell} \cdot \mathrm{s}$, and the ED $50: \mathrm{s} 218 \pm 124$ and $160 \pm 28 \mathrm{pmol} / 1$
\end{abstract}

(NS) in fat cells prepared from needle biopsy and surgically removed adipose tissue respectively. The mean coefficient of variation for maximal glucose transport in needle vs. surgical samples was $11 \pm 2 \%$. In 6 subjects, a surgical biopsy was taken twice, with a 1-week interval. The coefficient of variation averaged $9 \pm 2 \%$. We conclude that measurement of glucose transport rates can be done with similar accuracy using fat cells isolated from needle biopsy aspirates and surgically removed adipose tissue. Use of needle biopsy samples permits, however, study of glucose transport in repeat samples of human fat cells, and may therefore be a useful tool for any perturbation studies.

Key words: Adipocyte, glucose transport, insulin.
Insulin action in cells may be modulated by various mechanisms at either receptor- or postreceptor levels [1]. Especially in human cells, short-term regulatory events are insufficiently characterized due to limited availability of tissues. Acute studies have mostly been confined to measurement of insulin binding to blood cells [2-4]. Changes in the number and affinity of insulin receptors on blood cells correlate, however, poorly with those on other cell types $[5,6]$ and cannot yield information of insulin action. In adipose tissue both insulin binding and action can be measured, but sampling requires an open surgical biopsy, a procedure which cannot be repeated several times. In the present study we wanted to examine whether glucose transport could be measured from microsamples of adipose tissue obtained by needle biopsy aspiration.

\section{Subjects and methods}

\section{Subjects}

Adipose tissue was obtained from 29 healthy nonobese (BMI 19 to $24 \mathrm{~kg} / \mathrm{m}^{2}$ ), nondiabetic (fasting plasma giucose 4.7 to $5.2 \mathrm{mmol} / \mathrm{l}$ ) volunteers ( 15 men, 14 women) aged 21 to 35 years. Variation of the nee- dle biopsy method was assessed by comparing results from biopsies taken from the left and right gluteal region within $1 \mathrm{~h}$ from the same subject $(n=11)$.

To compare results obtained from fat removed by needle biopsy vs. surgically, needle biopsies were taken immediately prior to surgical biopsy from the lower abdominal region from 14 Pima Indians ( 8 men, 6 women, aged 18 to 33 years, BMI 26 to $51 \mathrm{~kg} / \mathrm{m}^{2}$, fasting plasma glucose 4.8 to $6.1 \mathrm{mmol} / \mathrm{l}$ ). To determine the reproducibility of glucose transport measurements from surgical samples, biopsies were taken from 6 Pima Indian men (aged 19 to 32 years, BMI 25 to $67 \mathrm{~kg}$ / $\mathrm{m}^{2}$, fasting plasma glucose 5.0 to $7.2 \mathrm{mmol} / \mathrm{l}$ ) twice with a 1-week interval. All these subjects were studied in the Phoenix Clinical Research Section after being stabilized for 5 or more days on a weight-maintenance diet ( $45 \%$ carbohydrate, $40 \%$ fat, $15 \%$ protein). All biopsies were taken between 07.30 and $08.30 \mathrm{~h}$ after a 12 -h overnight fast.

The nature, purpose and possible risks of the procedures were explained to all subjects before they gave their voluntary consent to participate. All subjects gave informed consent, and the studies were approved by the ethical committees of the Helsinki University Central Hospital, the National Institutes of Health and Indian Health Service, and by the Gila River Indian Community.

\section{Needle biopsy}

The skin was anaesthetized with $2 \mathrm{cc}$ of $1 \%$ lidocaine without epinephrine, taking care not to infiltrate subcutaneous or adipose tissue. The biopsy needle $(9 \mathrm{~cm} \times 2 \mathrm{~mm})$, attached to a 60 -cc tight-fitting glass 


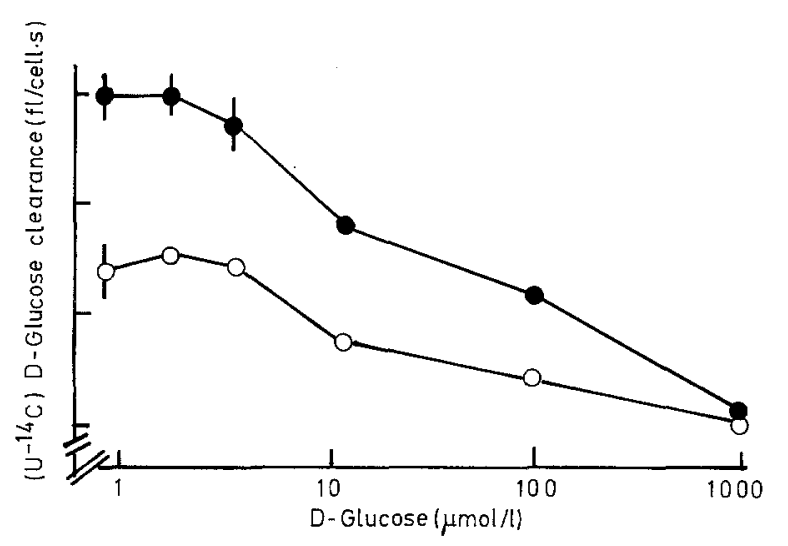

Fig. 1. Effect of extracellular glucose concentration on basal $(0)$ and maximally insulin-stimulated $(8 \mathrm{nmol} / 1$ insulin, $)$, glucose clearance rates

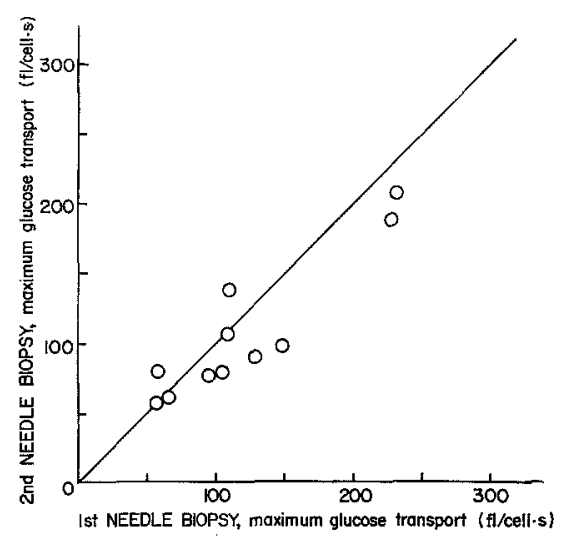

Fig. 2. Reproducibility of measurement of maximally insulin-stimulated (insulin $80 \mathrm{nmol} / 1$ ) glucose transport rates in two needle biopsy samples taken from the left and right gluteal region from the same subject. The coefficient of variation between the two measurements (method variation) for glucose transport averaged $11 \pm 6 \%$

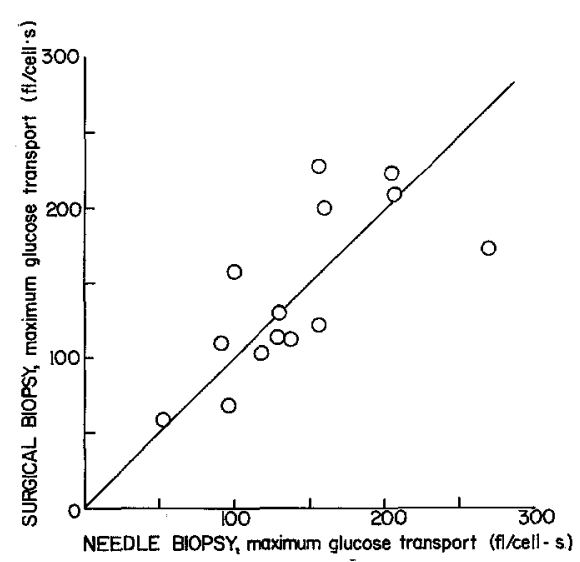

Fig.3. Comparison of maximal glucose clearance rates in fat cells isolated from needle biopsy samples vs. surgically removed fat. The coefficient of variation averaged $11 \pm 2 \%$

syringe was inserted through the infiltrated skin and small samples of adipose tissue were aspirated by vacuum suction outside the infiltrated area [7]. The amount of tissue obtained by two to three aspirations varied from 100 to $700 \mathrm{mg}$ (mean $300 \mathrm{mg}$ ). After each aspiration, the syringe was rinsed with Dulbecco's phosphate buffered saline $\left(20-23^{\circ} \mathrm{C}\right)$. The sample was subsequently poured into a plastic strainer, rinsed and transferred to polyethylene tubes containing collagenase buffer for isolation of cells [8].

\section{Surgical biopsy}

Subcutaneous adipose tissue $(5 \mathrm{~g})$ was removed from the lower abdomen, and the cells were isolated as previously described [8].

\section{Glucose transport}

Glucose transport was measured using $\mathrm{U}-\left({ }^{14} \mathrm{C}\right)$-D-glucose according to Foley et al. [9]. After isolation, adipocytes were transferred to Krebs-Ringer phosphate buffer $\left(37^{\circ} \mathrm{C}\right)$, pH 7.4, containing $5 \%$ bovine serum albumin. The assay was started by adding $50 \mu \mathrm{l}$ of a $20 \%$ cell suspension to tubes containing a trace amount of $\left(\mathrm{U}^{-14} \mathrm{C}\right)$-D-glucose $(0.2 \mu \mathrm{Ci} /$ tube, final concentration $1.5 \mu \mathrm{mol} / \mathrm{l})$ and various insulin concentrations $(0,25,50,100,200,800 \mathrm{pmol} / 1,8 ; 80 \mathrm{nmol} / 1)$. The incubations were carried out in triplicate at $37^{\circ} \mathrm{C}$ for $60 \mathrm{~min}$ with continuous shaking ( $40 \mathrm{cycles} / \mathrm{min}$ ) at a final volume of $500 \mu 1$. The incubation was terminated by centrifuging $350 \mu \mathrm{l}$ of cell suspension through $100 \mu \mathrm{l}$ silicone oil [10]. The cell-associated radioactivity and radioactivity remaining in the incubation medium were determined by liquid scintillation counting using $\mathrm{ACS}$ as liquid scintillator and Wallac liquid scintillation counter 81000 (LKB Wallac, Turku, Finland). The glucose transport rate was expressed as glucose clearance rate per cell as $\mathrm{fl} / \mathrm{cell} \cdot \mathrm{s}$ or per cell surface as al $/ \mu \mathrm{m}^{2} \cdot \mathrm{s}$.

\section{Determination of cell size}

Cell diameters were measured after fixation with osmium tetroxide as previously described [8]. The mean cell volume was converted to micrograms of lipid per cell using the correction factor of $0.91 \mu \mathrm{g} / \mathrm{nl}$ cell volume.

Chemicals. Collagenase (Clostridium histolyticum, no. C-2139, $250 \mathrm{U} / \mathrm{mg}$ ), was from Sigma (St. Louis, MO, USA), BSA from Finnish Red Cross (Helsinki, Finland) or Armour Pharmaceuticals (Kankakee, IL, USA), silicone oil from Dow Corning (Seneffe, Belgium), in sulin from Novo Research Institute (Bagsvaerd, Denmark), and U$\left({ }^{14} \mathrm{C}\right)$-D-glucose (sp. act. $300 \mathrm{mCi} / \mathrm{mmol}$ ) from the Radiochemical Centre (Amersham, England).

\section{Statistical analysis}

Statistical comparison was done using Student's paired or unpaired ttest. Results are expressed as mean $\pm \mathrm{SE}$.

\section{Results}

\section{Assay conditions}

Glucose transport in adipocytes obtained by needle biopsy was linearly related to fat cell concentration $(r=0.98)$ and time (basal clearance rate $22 \pm 1,42 \pm 3$, $64 \pm 4$ and $84 \pm 4 \mathrm{fl} /$ cell per s at $15,30,45$ and $60 \mathrm{~min}$ respectively, $n=3$ ). The coefficient of variation for triplicate samples was $11 \pm 1 \%$ for basal transport rates. To confirm that the concentration of glucose $(1.5 \mu \mathrm{mol} / \mathrm{l})$ was not too high to change the rate-limiting step in glucose utilization, basal and maximally stimulated glucose transport rates were measured in the presence of increasing glucose concentrations. Glucose transport 


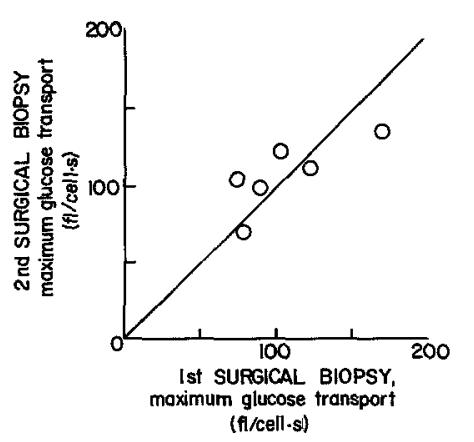

Fig.4. Comparison of maximal glucose transport rates using fat from two surgical fat biopsies from the same individual. The coefficient of variation was $9 \pm 2 \%$

remained constant up to approximately $5 \mu \mathrm{mol} / 1$ and declined thereafter (Fig. 1). Similar data have been reported previously in adipocytes obtained by surgical biopsy $[8,9]$.

\section{Reproducibility}

Needle vs. needle biopsy. In two needle biopsies taken from both sides of the gluteal region, the mean coefficient of variation of maximal clearance rates was $11 \pm$ $6 \%$ (Fig. 2). Basal glucose transport averaged $54 \pm 6$ and $51 \pm 6$, and maximum transport $122 \pm 18$ and $108 \pm$ $15 \mathrm{fl} /$ cell $\cdot \mathrm{s}(\mathrm{NS})$ in the first and second biopsy respectively.

Needle vs. surgical biopsy. The mean coefficient of variation for maximal glucose transport in needle vs. surgical samples was $11 \pm 2 \%$ (Fig. 3). The ED 50:s were $218 \pm$ 124 and $160 \pm 28 \mathrm{pmol} / 1$, basal transport rates $74 \pm 8$ and $57 \pm 6$, and maximal transport rates $143 \pm 15$ and $143 \pm 15 \mathrm{fl} / \mathrm{cell} \cdot \mathrm{s}$ in fat cells prepared from needle and surgical samples respectively (all NS).

Surgical vs. surgical biopsy. The coefficient of variation for maximal glucose transport averaged $9 \pm 2 \%$ (Fig. 4). Basal glucose transport averaged $40 \pm 4$ and $45 \pm 6$, maximal transport $108 \pm 9$ and $109 \pm 13 \mathrm{fl} / \mathrm{cell} \cdot \mathrm{s}$ and the ED 50:s $162 \pm 103$ and $148 \pm 55 \mathrm{pmol} / 1$ for the first and the second biopsy (all NS) respectively.

\section{Normal values}

Basal glucose transport rates were $1.3 \pm 0.2$ and $1.1 \pm$ $0.2 \mathrm{al} / \mu^{2} \cdot \mathrm{s}(\mathrm{NS})$ or $53 \pm 7$ and $36 \pm 6 \mathrm{fl} /$ cell $\cdot \mathrm{s}(p<$ 0.05 ) for females and males respectively. Maximal clearance rates were higher in females both when expressed per cell surface $\left(3.4 \pm 0.4\right.$ and $2.3 \pm 0.4 \mathrm{al} / \mu \mathrm{m}^{2} \cdot \mathrm{s}$ for $\mathrm{fe}-$ males and males, $p<0.05)$, and per cell $(136 \pm 17$ and $75 \pm 11 \mathrm{fl} /$ cell $\cdot \mathrm{s}$ respectively, $p<0.01$ ).

\section{Discussion}

In the present study, U-( $\left({ }^{14} \mathrm{C}\right)-\mathrm{D}$-glucose was chosen as the tracer for measurement of glucose transport since D-glucose uses $25-50 \%$ as many cells per sample as
3-O-methylglucose $[8,11]$. Furthermore, the coefficient of variation of parallel samples is about $20 \%$ for the $3-O-m e t h y l g l u c o s e$ assay $[8,11]$ but was only $5-10 \%$ for the D-glucose method of Foley et al. [9] and 11\% in this study. Finally, D-glucose is the natural substrate for the glucose transport system.

A large interindividual variation is frequently observed when glucose transport or some other metabolic process is measured in fat cells $[5,8,9,12]$. This variation could be due to true biological variation between individuals, or it could be caused by methodological variation. To distinguish between these two possibilities and to compare the reliability of needle biopsy samples to that of surgical samples, we studied the reproducibility of the glucose transport measurements using needle and/or surgical samples from the same individual. As judged from the coefficient of variation between two needle biopsies taken from the same subjects within $1 \mathrm{~h}$, the reproducibility was $11 \%$, i. e. small compared to the interindividual coefficient of variation ( $49 \%$ in Figure 2 for the first biopsy). We also studied the reproducibility of the measurements using fat cells from surgical samples. For ethical reasons, the surgical biopsies were taken 1 week apart. Thus, the observed coefficient of variation $(9 \%)$ may reflect not only method variation but also true intraindividual variation. We would expect the latter component to be small, however, since the subjects were admitted 5 days prior to the first biopsy, and their diet and physical activities habits were strictly controlled throughout the study. Comparison of glucose transport values from fat obtained by needle vs. surgically showed that neither the sensitivity nor the basal or maximal transport values were significantly influenced by the method of sampling. We may thus conclude that method variation is approximately the same for needle biopsy and surgical samples, and that this variation is small compared to the interindividual variation in glucose transport.

Normal values for glucose transport were calculated separately for men and women from the needle biopsy samples. In agreement with the findings of Pedersen et al. [13] in gluteal fat cells and Foley et al. [12] in abdominal fat cells, both basal and maximal glucose transport rates were higher in women than men when expressed per cell. The sex difference in basal glucose transport values disappeared when adjusting for the difference in cell size, whereas the maximally insulin-stimulated glucose transport rate in gluteal fat cells was, in keeping with the results of Foley et al. [12] in abdominal fat cells, higher in women than in men even when expressed per cell surface. Thus, gluteal as well as abdominal fat cells of females are more responsive to insulin than those of males. The finding of enhanced insulin action in females is in keeping with in vivo studies demonstrating higher rates of glucose disposal [14] and better glucose tolerance [15] in women than in men.

In conclusion, the present study indicates that the glucose transport system may be studied using micro- 
samples of human adipose tissue. Specifically, the assay described permits determination of the maximal glucose transport capacity and the insulin sensitivity (ED 50) of the fat cells. The reproducibility of the method is good, and therefore it may be used to detect differences both between subjects and changes in one subject in response to a physiological stimulus. The possibility to perform serial studies using insulin target tissue offers a tool to the study of acute changes in insulin action in normal man and in various patient groups.

Acknowledgements. The excellent technical assistance of Ms. H. Hilden, Ms. A.Salo, Ms. P. Thuillez and Ms. S. Moser is gratefully acknowledged. This study was supported by grants from the Finnish Medical Research Council (Academy of Finland) and Nordisk Insulinfond (Gentofte, Denmark).

\section{References}

1. Olefsky JM, Ciaraldi TP (1981) The insulin receptor: basic characteristics and its role in insulin resistant states. In: Brownlee $M$ (ed) Diabetes mellitus, islet cell function/insulin action, vol II. STPM Press, New York, pp 73-116

2. Muggeo M, Bar RS, Roth J (1977) Change in the affinity of insulin receptors following oral glucose in normal adults. J Clin Endocrinol Metab 44: 1206-1209

3. Insel JR, Kolterman OG, Saekow M, Olefsky JM (1980) Shortterm regulation of insulin receptor affinity in man. Diabetes 29 : 132-139

4. Baker B, Mandarino L, Brick B, Rizza R, Gerich J (1984) Influence of changes in insulin receptor binding during insulin infusions on the shape of the insulin dose-response curve for glucose disposal in man. J Clin Endocrinol Metab 58: 392-396

5. Pedersen O, Hjollund E (1982) Insulin receptor binding to fat and blood cells and insulin action in fat cells from insulin-dependent diabetics. Diabetes 31: 706-715

6. Taylor R, Proctor SJ, James O, Clark F, Alberti KGMM (1984)
The relationship between human adipocyte and monocyte binding. Clin Sci 67: 139-142

7. Taskinen M-R, Nikkilä EA, Huttunen JK, Hilden H (1980) A micromethod for assay of lipoprotein lipase activity in needle biopsy samples of human adipose tissue and skeletal muscle. Clin Chim Acta 104: 107-117

8. Kashiwagi A, Verso MA, Andrews J, Vasquez B, Reaven G, Foley JE (1983) In vitro insulin resistance of human adipocytes isolated from subjects with non-insulin-dependent diabetes mellitus. $\mathrm{J}$ Clin Invest 72: 1246-1254

9. Foley JE, Kashiwagi A, Verso MA, Reaven G, Andrews JA (1983) Improvement in in vitro insulin action after one month of insulin therapy in obese non-insulin dependent diabetics. J Clin Invest 72:1901-1909

10. Gliemann J, Sonne O (1978) Binding and receptor-mediated degradation of insulin in adipocytes. J Biol Chem 253: 7857-7863

11. Pedersen O, Gliemann J (1981) Hexose transport in human adipocytes: Factors influencing the response to insulin and kinetics of methylglucose and glucose transport. Diabetologia 20:630-635

12. Foley JE, Kashiwagi $A$, Chang $H$, Huecksteadt TP, Lillioja S, Verso MA, Reaven GM (1984) Sex differences in insulin-stimulated glucose transport in rat and human adipocytes. Am J Physiol 246: E211-E215

13. Pedersen O, Hjollund E, Lindskov HO (1982) Insulin binding and action on fat cells from young healthy females and males. Am J Physiol 243: E158-E167

14. Yki-Järvinen H (1984) Sex and insulin sensitivity. Metabolism 33: 1011-1015

15. Krotkiewski M, Bjorntorp P, Sjostrom L, Smith U (1983) Impact of obesity on metabolism in men and women. Importance of regional adipose tissue distribution. J Clin Invest 72: 1150-1162

Received: 9 May 1985

and in revised form: 3 February 1986

Dr. Hannele Yki-Järvinen

Clinical Diabetes and Nutrition Section

NIADDK/NIH

4212 North 16 th Street

Phoenix, AZ 85016

USA 